\title{
Genetical and physicochemical diversity among twelve Brazilian cultivars of cashew (Anacardium occidentale)
}

\section{Diversidad genética y fisicoquímica en doce cultivares brasileños de anacardo (Anacardium occidentale)}

\section{Acta Botanica Mexicana}

\author{
Moaciria de Souza Lemos' (iD), Patricia do Nascimento Bordallo33 (iD), Francisco das Chagas Vidal Neto³ (iD), Eveline \\ Nogueira Lima², iD, Ioná Santos Araújo Holanda 4 iD
}

\begin{abstract}
:
Background and Aims: Cashew (Anacardium occidentale) is a native Brazilian tree, cultivated in various warm climates across the world. The cashew kernels production has been an important economic activity for many tropical countries, providing a variety of food with great nutrition value. The genetic diversity among the early dwarf cultivars used to production is poorly understood, as is the nutritional composition among nuts from those plants. This work aimed to evaluate the physicochemical characteristics of cashew kernels and to study genetic diversity among twelve cultivars to indicate superior genotypes for future breeding programs.

Methods: Cashew kernels from twelve cultivars were evaluated for $\mathrm{pH}$, titratable acidity, moisture, ash, lipids and proteins. The genetic variability was assessed using RAPD and ISSR molecular markers. Data from molecular and physicochemical analyses were used to estimate the genetic distances and Mantel test approach was applied to calculate Pearson's correlation between the data.

Key results: A high genetic variability was found among the cultivars. BRS 274 and BRS 275 were the closest genetically, while CCP 09 and BRS 189 were the most distant ones. On the other hand, EMBRAPA 51 and BRS 226 showed cashew kernels with more similar physicochemical characteristics, while BRS 189 and BRS 253 had the more different ones. Moreover, no correlation was found between the physicochemical and molecular results. Cashew kernels had pH close to neutrality, low acidity, considerable moisture content, and high lipid and protein contents.

Conclusions: The cashew kernels from the cultivars studied here had low acidity and pH, considerable moisture and ash contents, and high protein and lipid contents. BRS 189, BRS 253, and CCP 1001 showed the best values for proteins, lipids, acidity, and pH. In addition, those cultivars have maximum distance genetic among them, which can be used as parents in future gene combinations in breeding programs.
\end{abstract}

Key words: breeding, genetic resources, molecular markers.

\section{Resumen:}

Antecedentes y Objetivos: El marañón (Anacardium occidentale) es un árbol nativo de Brasil y cultivado en varios climas cálidos en todo el mundo. La producción de nueces de marañón ha sido una actividad económica importante para muchos países tropicales, proporcionando una variedad de alimentos con un gran valor nutricional. La diversidad genética entre los primeros árboles de marañón enanos utilizados para la producción es poco conocida, así como la composición nutricional entre los frutos secos de estas plantas. Este trabajo tuvo como objetivo evaluar las características fisicoquímicas de los granos de marañón y estudiar la diversidad genética entre doce cultivares para indicar genotipos superiores para futuros programas de mejoramiento.

Métodos: Se evaluó el pH, acidez titulable, humedad, ceniza, lípidos y proteínas de los granos de marañón de doce cultivares. La variabilidad genética se evaluó mediante marcadores moleculares RAPD e ISSR. Se utilizaron datos de análisis moleculares y fisicoquímicos para estimar las distancias genéticas y se aplicó el método de prueba de Mantel para calcular la correlación de Pearson entre los datos.

Resultados clave: Se encontró una alta variabilidad genética entre los cultivares. BRS 274 y BRS 275 fueron los más cercanos genéticamente, mientras que CCP 09 y BRS 189 fueron los más distantes. Por otro lado, EMBRAPA 51 y BRS 226 mostraron granos con características fisicoquímicas más similares, mientras que BRS 189 y BRS 253 tuvieron los más diferentes. Además, no se encontró correlación entre los resultados fisicoquímicos y moleculares. Los granos de marañón tenían un $\mathrm{pH}$ cercano a la neutralidad, baja acidez, considerable contenido de humedad y alto contenido de lípidos y proteínas.

Conclusiones: Los granos de marañón de los doce cultivares estudiados aquí tenían baja acidez y pH, contenido considerable de humedad y cenizas, y alto contenido de proteínas y lípidos. BRS 189, BRS 253 y CCP 1001 mostraron los mejores valores de proteínas, lípidos, acidez y pH. Además, esos cultivares tienen una distancia genética máxima entre ellos, que pueden usarse como progenitores en futuras combinaciones de genes en programas de mejoramiento genético. Palabras clave: marcadores moleculares, mejoramiento genético, recursos genéticos.

\footnotetext{
${ }^{1}$ Universidade Federal do Ceará, Campus do Pici, Departamento de Bioquímica e Biologia Molecular, Laboratório de Metabolismo de Plantas, Avenida Mister Hull 2002, Presidente Kennedy, 60356-000 Fortaleza, Ceará, Brasil.

${ }^{2}$ Universidade Federal do Ceará, Campus do Pici, Departamento de Fitotecnia, Avenida Mister Hull s/n, Presidente Kennedy, 60455-760 Fortaleza, Ceará, Brasil.

${ }^{3}$ Embrapa Agroindústria Tropical, Rua Dra. Sara Mesquita 2270, Pici, 60511-110 Fortaleza, Ceará, Brasil.

${ }^{4}$ Universidade Federal Rural do Semi-Árido, Campus Mossoró, Departamento de Ciências Vegetais, Laboratório de Biotecnologia Vegetal, Rua Francisco Mota 572, Presidente Costa e Silva, 59625-900 Mossoró, Rio Grande do Norte, Brasil.
}

\section{${ }^{5}$ Author for correspondence: evelinenlima@gmail.com}

Received: August 17, 2020.

Reviewed: November 3, 2020.

Accepted by Marie-Stéphanie Samain: April 9, 2021.

Published Online first: April 20, 2021.

Published: Acta Botanica Mexicana 128 (2021).
To cite as:

de Souza Lemos, M., P. do Nascimento Bordallo, F. das Chagas Vidal Neto, E. Nogueira Lima and I. S. Araújo Holanda. 2021. Genetical and physicochemical diversity among twelve Brazilian cultivars of cashew (Anacardium occidentale). Acta Botanica Mexicana 128: e1775: DOI: https://doi.org/10.21829/abm128.2021.1775
This is an open access article under the Creative Commons 4.0 Attribution-Non commerBY-NC 4.0 International). 


\section{Introduction}

Cashew (Anacardium occidentale L.) is native to Brazil and grown in tropical regions to produce cashew kernels, one of the edible nuts most commercialized on the international market (Brainer and Vidal, 2018) (Fig. 1). Brazilian production of cashew is concentrated in the northeastern region of the country, where the plant has socioeconomic importance, mainly in the semiarid region, for generating jobs and income in the dry season (Brainer and Vidal, 2018). In 2020, the Brazilian production of cashew nuts reached about 429,316 tons (IBGE, 2020).

In Brazil, the production of cashew nuts increased due to the introduction of early dwarf cashew cultivars in the 1980s (Figueirêdo et al., 2016). These cultivars are more productive, easy to grow, and more disease resistant than other commercial cultivars. However, there is currently a small number of cashew cultivars. Thus, it becomes necessary to identify kinship relationships between cashew cultivars to select genotypes with favorable characteristics for cultivation and consumption, such as plant height, disease resistance and nutritional quality of the kernel (Serrano and Pessoa, 2016).

The cashew tree is mainly known for the production of two natural products: the cashew nut (the fruit) and the pseudofruit (an expanded and fleshy peduncle) (Fig. 1C, $D, E, F)$. The nuts (main commercial product) have a much broader market. They are consumed in nature as whole almonds or fragmented which are mainly used as recipe
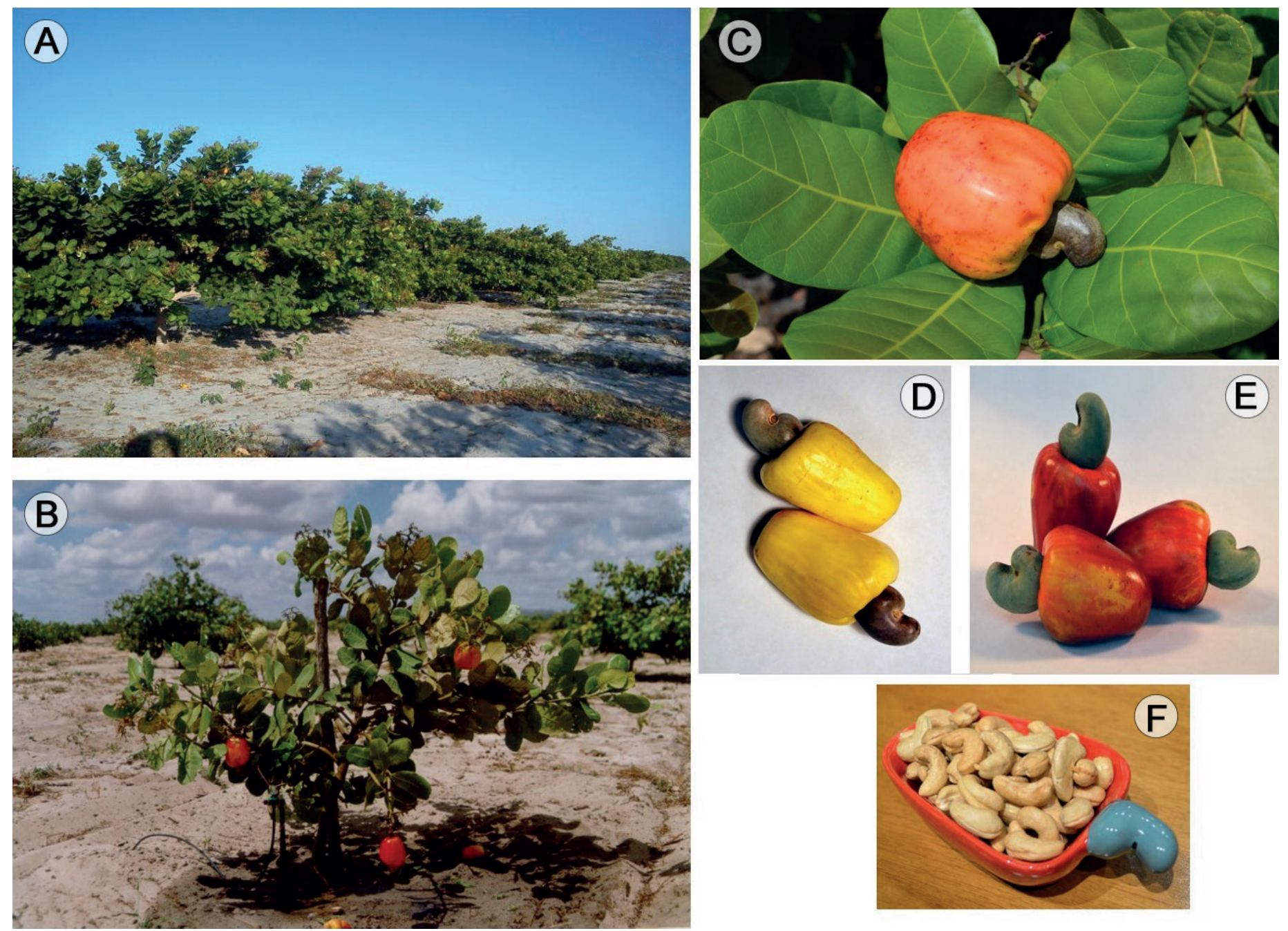

Figure 1: Morphological aspects from early dwarf cashew. A. early dwarf trees plantation; B. early dwarf cultivar BRS 189; C. fruit and pseudofruit of BRS 226; D. fruit and pseudofruit of EMBRAPA 50; E. fruit and pseudofruit of CCP 1001; F. cashew nuts. Sources: A. Luiz Augusto L. Serrano; B. Cláudio Norões; C-F. Ana Elisa Sidrim. 
ingredients (cakes, pastries, candies and chocolates), enriching their taste and appearance (Gadani et al., 2017). The peduncle is largely consumed as fresh fruit and in the form of juice and derivatives (Carneiro et al., 2019).

Despite the great foreign market designed especially for nuts consumption, the peduncle, although it has good potential for industrialization, has been poorly explored (Freitas et al., 2020). Therefore, a great improvement to the industry of such attractive products would be generating cultivars with both quality desirable for peduncles and nuts consumption. As shown in Table 1, Brazilian early dwarf cashew cultivars have great advantage, because it is possi- ble to find plants specifically reliable to peduncle consumption, such as BRS 189, and for the nuts market, as such BRS 274 and 275, which have higher cashew nuts production (Cavalcanti and Barros, 2009).

Studies on genetic divergence provide parameters for identifying potential parents for crossbreeding that generate a greater heterotic effect, heterozygosity, and the probability of obtaining superior genotypes in segregating generations (Sethi et al., 2016). In cashew, for example, it is interesting to improve the characteristics of its kernels, such as size and nutritional quality. This is because from larger and healthier cashew nuts (high nutritional value),

Table 1: Main agro-industrial characteristics of 6-year-old cashew cultivars under experimental conditions in the municipality Pacajus, Ceará state (CE), Brazil. Sources: Cavalcanti and Barros, 2009; Cavalcanti et al., 2013; Vidal Neto et al., 2013.

\begin{tabular}{|c|c|c|c|c|c|c|}
\hline Cultivars & Type & $\begin{array}{l}\text { Peduncle } \\
\text { color }\end{array}$ & $\begin{array}{l}\text { Mean } \\
\text { peduncle } \\
\text { weight }(g)\end{array}$ & $\begin{array}{l}\text { Nut } \\
\text { weight } \\
\text { (g) }\end{array}$ & $\begin{array}{l}\text { Kernel } \\
\text { weight (g) }\end{array}$ & Parental relation \\
\hline СCP 06 & Early dwarf & yellow & 76.5 & 6.4 & 1.6 & CP 06 (dwarf) individual phenotypic selection \\
\hline ССР 09 & Early dwarf & orange & 87 & 7.7 & 2.1 & CP 09 (dwarf) individual phenotypic selection \\
\hline СCP 76 & Early dwarf & orange & 135 & 8.6 & 1.80 & CP 76 (dwarf) individual phenotypic selection \\
\hline CCP 1001 & Early dwarf & orange & 84.6 & 7.0 & 1.90 & CP 1001 (dwarf) individual phenotypic selection \\
\hline EMBRAPA 50 & Early dwarf & yellow & 111 & 11.2 & 2.9 & $\begin{array}{l}\text { individual phenotypic selection in CP } 06 \text { (dwarf) } \times \text { CP } \\
07 \text { (common) progeny }\end{array}$ \\
\hline EMBRAPA 51 & Early dwarf & reddish & 104 & 10.4 & 2.6 & phenotypic selection in a polycross progeny \\
\hline BRS 253 & Early dwarf & reddish & 91.3 & 10.2 & 2.7 & 96 (P96D) \\
\hline BRS 274 & common clone & orange & 128.6 & 16 & 16.00 & $\begin{array}{l}\text { individual phenotypic selection in a segregated } \\
\text { population }\end{array}$ \\
\hline BRS 275 & $\begin{array}{l}\text { hybrid between } \\
\text { an early dwarf } \\
\text { and a common } \\
\text { clone common }\end{array}$ & orange & 108 & 11.0 & 11.4 & $\begin{array}{l}\text { individual phenotypic selection within CCP } 1001 \\
\text { (dwarf) × CP } 12 \text { (giant common) control-pollinated } \\
\text { progeny }\end{array}$ \\
\hline BRS 226 & & orange & 102.6 & 9.75 & 2.72 & individual phenotypic selection \\
\hline BRS 189 & Early dwarf & reddish & 155.4 & 7.9 & 2.1 & $\begin{array}{l}\text { individual phenotypic selection within CCP } 1001 \\
\text { (dwarf) } \times \text { CCP } 76 \text { (dwarf) control-pollinated } \\
\text { progeny }\end{array}$ \\
\hline BRS 265 & Early dwarf & reddish & 118,2 & 12.5 & 2.8 & $\begin{array}{l}\text { individual phenotypic selection within CCP } 76 \\
\text { (dwarf) open pollinated progeny }\end{array}$ \\
\hline
\end{tabular}


the industry offers good products to obtain higher consumption standards. Therefore, larger nuts are more attractive to consume as whole nuts, a larger market with higher prices. In addition, the large widespread consumption of cashew nuts is due to its nutritional properties. These properties are mainly linked to the high content of lipids and proteins (Salehi et al., 2019; Oliveira et al., 2020).

Such studies have been widely carried out from the implementation of molecular tools such as RAPD (Random Amplified Polymorphic DNA) and ISSR (Inter Simple Sequence Repeats) markers. Both markers are highly polymorphic, of low cost, and easily used in experiments. In addition, using more primers with different sequences increases the coverage of the plant genome by allowing access to distinct genomic regions (Nadeem et al., 2018).

The markers used in this work can access different regions of the DNA, performing a great screening to inform the differences between genetically close plants. The use of molecular markers has been promising in the study of genetic variability in cashew germplasm (Sethi et al., 2016; Thimmappaiah et al., 2016). This work also aimed to evaluate the physicochemical characteristics of almonds from twelve cashew cultivars and to study the genetic diversity among them to identify superior genotypes for future breeding programs.

\section{Material and Methods}

\section{Description of cashew cultivars and sampling}

Twelve cashew cultivars were evaluated. Among them, ten were early dwarf (CCP 06, CCP 09, CCP 76, CCP 1001, EMBRAPA 50, EMBRAPA 51, BRS 189, BRS 226, BRS 253, BRS $265)$, one hybrid between an early dwarf and a common clone (BRS 275), and one common clone (BRS 274) (Table 1). All cultivars were from the Cashew Breeding Program of Embrapa Agroindústria Tropical, Fortaleza, Ceará state, Brazil. Figure 2 shows the geographic origin of cultivars.

Leaf and kernel samples for each cultivar were collected from trees located on the experimental field of the Embrapa Agroindústria Tropical Cashew Germplasm Bank (BAG Cashew), in Pacajus, Ceará, Brazil. All trees in the BAG Cashew are identified, documented, characterized, and subsamples of all accessions are deposited in the Germplasm Bank of Embrapa Recursos Genéticos and Biotecnologia, Brasilia, an accredited institution for reference samples.
Ten cashew nuts of each cultivar were manually harvested and detached from the peduncle and sent to the Laboratory of Biochemistry, at the Universidade Federal Rural do Semi-Árido, Mossoró, Rio Grande do Norte, Brazil. Plastic bags with kernels were kept at room temperature until the start of the experiments. The young leaves of the same cultivars were collected, stored in plastic bags and kept on ice until reaching the Laboratory of Plant Biotechnology, at the Universidade Federal Rural do Semi-Árido, Mossoró, Rio Grande do Norte, Brazil. Samples were then stored at $-20{ }^{\circ} \mathrm{C}$ temperature and DNA isolation was performed next.

\section{Physicochemical traits evaluation}

The physicochemical traits were evaluated from previously steamed cashew kernels. Upon steaming, cashew kernels were dried at room temperature and then crushed in a mortar. The following parameters were analyzed, following methods described by the Adolfo Lutz Institute (IAL, 2008): $\mathrm{pH}$, titratable acidity, moisture, ash, lipids, and proteins (Table 2).

The BRS 253 cultivar was discarded from this part of the study because, at the beginning of the experiment, cashew kernels from this clone had high moisture due to the peel removal. During the execution of the experiments, it was hard to obtain more samples from this cultivar.

For $\mathrm{pH}$ analysis, a $3.0 \mathrm{~g}$ fresh nut was placed in $30 \mathrm{ml}$ of distilled water, and the $\mathrm{pH}$ was measured directly with a potentiometer (Fisherbrand ${ }^{\mathrm{TM}}, \mathrm{AE150}$, Massachusetts, USA). This same solution was used to determine acidity. For this purpose, three drops of phenolphthalein were added and then the solution was titrated with $0.1 \mathrm{M}$ sodium hydroxide $(\mathrm{NaOH})$. In the $\mathrm{pH}$ analysis, the concentration of free hydrogen ions $\left(\mathrm{H}_{3} \mathrm{O}^{+}\right)$in solution is determined. Acidity is a measure of the organic acids present in the solution, which can be either weak acids (they do not completely dissociate in water) or strong acids (they completely dissociate in water).

Many acids cannot completely dissociate in water. These acids have a low dissociation constant (Ka), generating a low concentration of $\mathrm{H}_{3} \mathrm{O}^{+}$in solution. This can cause differences in the values of acidity and $\mathrm{pH}$, as the acidity can be high, but the composition of acids can be mostly weak acids, generating little $\mathrm{H}_{3} \mathrm{O}^{+}$in solution and low $\mathrm{pH}$ value. 


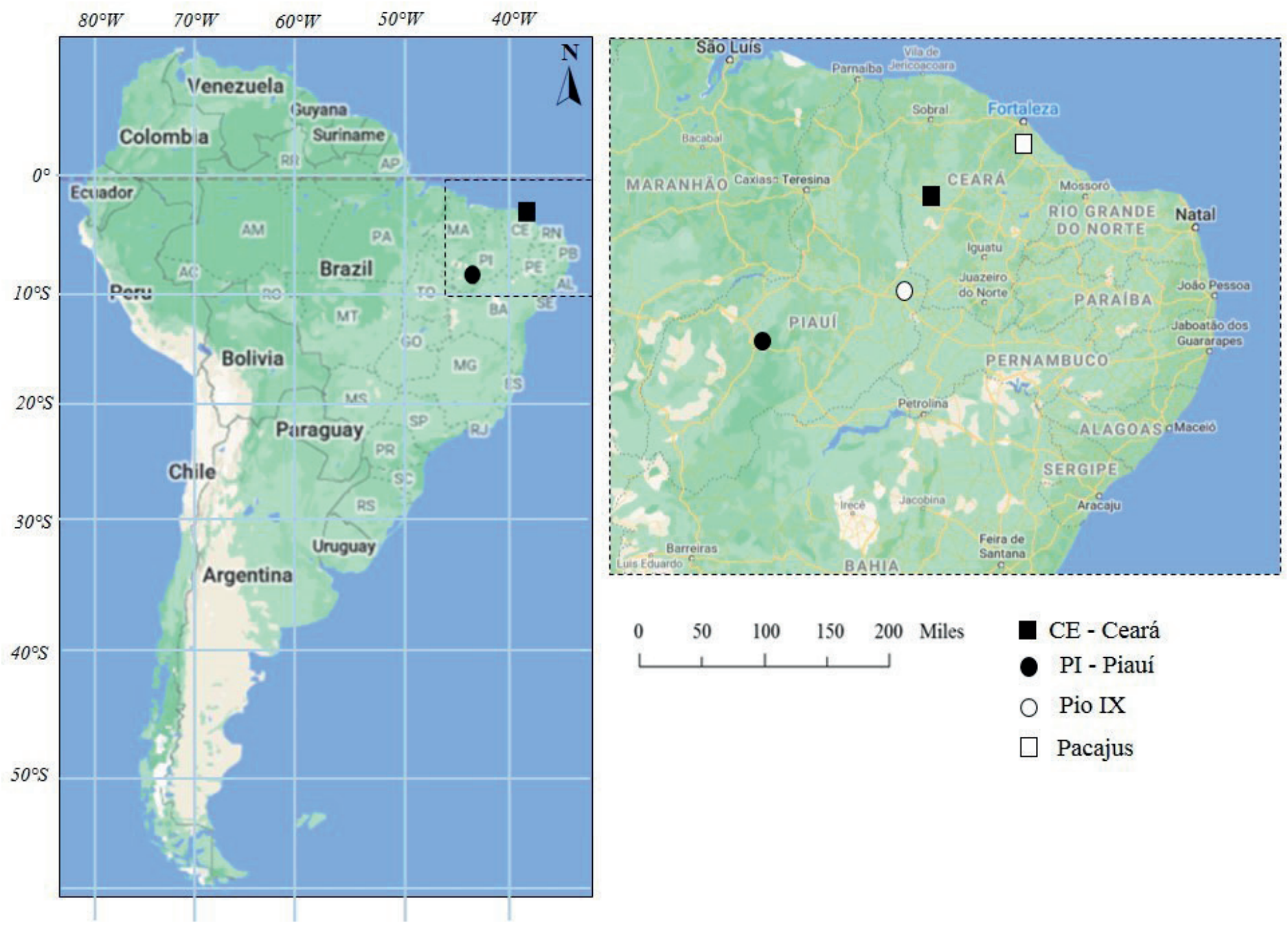

Figure 2: Geographic origin of cashew tree for this study in Brazil. Pacajus (-4.17398, -38.4638) at the Ceará and Pio IX (-6.84773, -40.5836$)$ at the Piauí.

To determine moisture, $5.0 \mathrm{~g}$ of fresh nut weighed in a porcelain crucible were dried in an oven (at $105^{\circ} \mathrm{C}$ for $4 \mathrm{~h}$ ) and then in a desiccator. For ashes, $2.0 \mathrm{~g}$ of dried nut from moisture analysis weighed in a crucible were placed in a muffle at $550^{\circ} \mathrm{C}$ and kept for $6 \mathrm{~h}$, and then the sample was weighed, after being cooled in a desiccator.

Lipids were extracted using hexane in a Soxhlet extractor (HMK21043, Beijing, China). 1.0 g sample weighed (dried nut) in a cartridge was dissolved with $125 \mathrm{ml}$ hexane. Then, the residue was placed in an oven at $105^{\circ} \mathrm{C}$ and in a desiccator.

Crude protein was determined according to the Kjeldahl Method (Kirk, 1950). $0.5 \mathrm{~g}$ of sample (dried nut) was digested with $200 \mathrm{mg}$ of catalytic mixture (potassium sulfate and copper sulfate at 9:1 ratio) and $5 \mathrm{ml}$ of sulfuric acid. Then, the digested solution was distilled using $20 \mathrm{ml}$ of $\mathrm{NaOH}(40 \%), 10 \mathrm{ml}$ of boric acid (4\%), and a mixed indicator (bromocresol green and methyl red) to receive the ammonia released in the chemical reaction. Subsequently, the distillate obtained was titrated with $0.1 \mathrm{~N}$ hydrochloric $\operatorname{acid}(\mathrm{HCl})$.

The physicochemical characteristics of cashew kernels $(\mathrm{pH}$, titratable acidity, moisture, ash, lipids, and proteins) were evaluated in triplicate in a completely randomized experimental design. Data were submitted to one-way analysis of variance (one factor = cashew cultivars), and the 
Table 2: Physicochemical characterization of twelve cashew cultivars kernels.

\begin{tabular}{|c|c|c|c|c|c|c|}
\hline $\begin{array}{l}\text { Cultivars } \\
\text { Identification }\end{array}$ & $\mathrm{pH}(\%)$ & Acidity (\%) & Moisture (\%) & Ashes (\%) & Proteins (\%) & Lipids (\%) \\
\hline EMBRAPA 50 & 6.98 & 0.78 & 7.36 & 2.80 & 29.4 & 43.5 \\
\hline EMBRAPA 51 & 6.73 & 0.70 & 5.98 & 2.78 & 26.6 & 48.4 \\
\hline СCP 06 & 6.92 & 0.71 & 7.20 & 3.06 & 30.9 & 48.5 \\
\hline ССР 09 & 6.80 & 0.88 & 6.02 & 2.72 & 23.6 & 46.5 \\
\hline CCP 76 & 6.82 & 0.90 & 7.73 & 3.09 & 27.1 & 44.2 \\
\hline ССР 1001 & 6.92 & 0.73 & 3.36 & 2.27 & 27.4 & 46.8 \\
\hline BRS 189 & 6.91 & 0.85 & 6.00 & 2.94 & 34.2 & 39.7 \\
\hline BRS 226 & 6.80 & 0.81 & 6.61 & 2.80 & 25.7 & 50.3 \\
\hline BRS 253 & 6.81 & 0.76 & 12.50 & 2.53 & 29.6 & 54.6 \\
\hline BRS 265 & 6.89 & 0.84 & 6.78 & 2.93 & 31.0 & 47.6 \\
\hline BRS 274 & 6.83 & 0.90 & 6.24 & 2.35 & 26.3 & 54.0 \\
\hline BRS 275 & 6.76 & 0.81 & 7.99 & 2.88 & 31.6 & 46.2 \\
\hline Mean & 6.85 & 0.81 & 6.98 & 2.76 & 28.62 & 47.53 \\
\hline Standard deviation & 0.08 & 0.07 & 2.11 & 0.26 & 3.01 & 4.19 \\
\hline
\end{tabular}

significant differences between the means of each genotype were evaluated by the Tukey test at $5 \%$ probability level in Past software v. 4.03 (Hammer et al., 2001).

To assess the physicochemical diversity among cashew cultivars, we used an UPGMA cluster analysis, as implemented in the software Genes v. 2013 (Cruz, 2013). A genetic dissimilarity matrix was constructed using the Euclidean coefficient and a cluster analysis by ANOVA was performed based on the mean of the distances. To validate this clustering, the cophenetic correlation coefficient (CCC) was calculated using the dissimilarity between the cultivars as a measure of genetic distance.

\section{DNA analysis}

DNA was extracted from fresh leaves of each cultivar using the CTAB method as described by Ferreira and Grattapaglia (1995). Then, the DNA quality was checked using electrophoresis under $80 \mathrm{~V}$ for $30 \mathrm{~min}$ in $1 \%$ agarose gel stained with ethidium bromide $\left(10 \mathrm{mg} \mathrm{ml}^{-1}\right)$. Subsequently, the gel was photographed under UV light on an image system (BioRad, Gel Doc 2000, San Diego, USA) and the samples were compared with DNA quantification standard from DNA lambda for further dilution to $10 \mathrm{ng} \mathrm{\mu l}^{-1}$.

The DNA samples were amplified using eight ISSR primers (Table 3 ). The amplification reactions comprised a
$12 \mu$ l final volume, containing $1.2 \mu \mathrm{l}$ of $10 \mathrm{X}$ reaction buffer (20 mM Tris- $\mathrm{HCl} \mathrm{pH} \mathrm{8.0,} 100 \mathrm{mM} \mathrm{KCl}$, and $3.2 \mathrm{mM} \mathrm{MgCl}_{2}$ ), 1.0 $\mu$ l of dNTP $(0.25 \mathrm{mM}), 2.0 \mu \mathrm{l}$ of DNA $\left(10 \mathrm{ng}_{\mu \mathrm{l}^{-1}}\right), 2.0 \mu \mathrm{l}$ of each

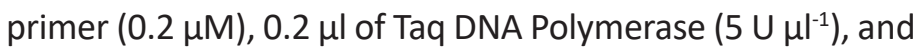
ultrapure water $(5.6 \mu \mathrm{l})$. The amplification reactions were carried out in a thermocycler (Bio-Rad, Gel Doc 2000, San Diego, USA), programmed for an initial denaturation (at 94 ${ }^{\circ} \mathrm{C}$ for $4 \mathrm{~min}$ ), followed by 35 cycles of denaturation (at 94 ${ }^{\circ} \mathrm{C}$ for $40 \mathrm{~s}$ ), annealing (at 40,45 or $50^{\circ} \mathrm{C}$, depending on the primer), and an extension (at $72^{\circ} \mathrm{C}$ for $1 \mathrm{~min}$ ), followed by a final extension (at $72{ }^{\circ} \mathrm{C}$ for $2 \mathrm{~min}$ ). Successful amplification was checked by agarose electrophoresis (1.5\% agarose gel ran for $220 \mathrm{~min}$ at $110 \mathrm{~V}$, stained with $10 \mathrm{mg} \mathrm{ml}^{-1}$ ethidium bromide, and visualized under UV light on an image system (Bio-Rad, Gel Doc 2000, San Diego, USA).

The RAPD markers were obtained from amplifications with 15 arbitrary primers (Table 3 ) in reactions with a final volume of $12 \mu \mathrm{l}$. Reactions were prepared under the same conditions as described for the ISSR markers, except that primer concentration was $0.33 \mu \mathrm{M}$. Amplification was performed in a thermocycler (Bio-Rad, PTC- $100^{\circledR}$, California, USA) programmed for an initial denaturation at $94{ }^{\circ} \mathrm{C}$ for 5 min followed by 40 cycles consisting of: denaturation at $94{ }^{\circ} \mathrm{C}$ for $30 \mathrm{~s}$, annealing at $40{ }^{\circ} \mathrm{C}$, and extension at $72{ }^{\circ} \mathrm{C}$ for $1 \mathrm{~min}$; followed by a final extension at $72{ }^{\circ} \mathrm{C}$ for $7 \mathrm{~min}$. 
Table 3: The extent of DNA polymorphism in twelve cashew cultivars generated by eight different ISSR and 15 RAPD primers. Tm=annealing temperature, NAF=number of amplified of fragments, NPF=number of polymorphic fragments. * $R=A / G ; Y=C / T$. Adapted from Santana et al. (2011), with modifications.

\begin{tabular}{|c|c|c|c|c|c|}
\hline Primer $\left(5^{\prime}-3^{\prime}\right)$ & Nucleotide sequence (5'-3') & $\operatorname{Tm}\left({ }^{\circ} \mathrm{C}\right)$ & NAF & NPF & $\begin{array}{c}\text { \% Polymorphic } \\
\text { loci }\end{array}$ \\
\hline \multicolumn{6}{|l|}{ ISSR } \\
\hline DiGA3'C & GAGAGAGAGAGAGAGAC & 45 & 4 & 4 & 100 \\
\hline DiGA3'T & GAGAGAGAGAGAGAGAT & 40 & 6 & 6 & 100 \\
\hline TriAAG 3'RC & AAGAAGAAGAAGAAGRC & 40 & 3 & 2 & 66.6 \\
\hline TriAGG 3'RC & AGGAGGAGGAGGAGGRC & 45 & 5 & 5 & 100 \\
\hline TriTCA 3'RC & TCATCATCATCATCARC & 40 & 4 & 4 & 100 \\
\hline TriTCT 3'RC & TCTTCTTCTTCTTCTRC & 40 & 3 & 3 & 100 \\
\hline TriCAT 3'RC & CATCATCATCATCATRC & 50 & 7 & 7 & 100 \\
\hline \multirow[t]{3}{*}{ TriCGA 3'RC } & CGACGACGACGACGARC & 45 & 3 & 3 & 100 \\
\hline & Total & & 35 & 34 & \\
\hline & Mean & & 4.3 & 4.2 & 95.8 \\
\hline \multicolumn{6}{|l|}{ RAPD } \\
\hline OPA 01 & CAGGCCCTTC & 40 & 5 & 4 & 100 \\
\hline OPA 02 & TGCCGAGCTG & 40 & 14 & 14 & 100 \\
\hline OPA 07 & GAAACGGGTG & 40 & 5 & 4 & 80 \\
\hline OPA 08 & GTGACGTAGG & 40 & 10 & 10 & 100 \\
\hline OPA 10 & GTGATCGCAG & 40 & 6 & 6 & 100 \\
\hline OPA 12 & TCGGCGATAG & 40 & 7 & 7 & 100 \\
\hline OPA 14 & TCTGTGCTGG & 40 & 7 & 7 & 100 \\
\hline OPA 19 & CAAACGTCGG & 40 & 11 & 11 & 100 \\
\hline OPAA 03 & TTAGCGCCCC & 40 & 4 & 4 & 100 \\
\hline OPAA 07 & CTACGCTCAC & 40 & 8 & 8 & 100 \\
\hline OPD 05 & TGAGCGGACA & 40 & 9 & 9 & 100 \\
\hline OPD 09 & CTCTGGAGAC & 40 & 9 & 9 & 100 \\
\hline OPH 01 & GGTCGGAGAA & 40 & 9 & 9 & 100 \\
\hline OPH 07 & CTGCATCGTG & 40 & 7 & 7 & 100 \\
\hline \multirow[t]{3}{*}{ OPH 10} & CCTACGTCAG & 40 & 11 & 11 & 100 \\
\hline & Total & & 122 & 120 & \\
\hline & Mean & & 8.1 & 9.2 & 98.6 \\
\hline
\end{tabular}

The amplification products were subjected to agarose electrophoresis under the same conditions as described for the ISSR markers.

\section{Statistical analyses}

Based on the analysis of the band pattern produced by each primer (RAPD and ISSR), a binary matrix was built with both molecular markers, attributing number one to the presence and zero to the absence of polymorphic bands. From the presence/absence matrix, a genetic dissimilarity matrix was obtained using the Euclidean coefficient, which was used as input for cluster analysis using the UPGMA clustering method (Faleiro, 2007), as implemented in the software Statistica v. 8 (Weiß, 2007). To compare the genetic diversity among the cultivars using the RAPD and ISSR markers and physicochemical attributes, a Mantel test ap- 
proach to calculate Pearson's correlation coefficient between the dissimilarity matrices was implemented in the software Statistica v. 8 (Weiß, 2007).

\section{Results}

\section{Physicochemical traits}

Cashew kernels from the twelve cashew cultivars evaluated showed $\mathrm{pH}$ values close to neutrality, 6.8 on average. Acidity was $0.81 \%$ on average, with values ranging from $0.70 \%$ to $0.90 \%$, which corresponded to EMBRAPA 51 and BRS 274, respectively. The standard deviation was low (0.0007), so that no significant difference for acidity was observed among cultivars, according to the $\mathrm{F}$ test at $5 \%$ probability level. Moisture in cashew kernels was 6.69\% on average, with 0.021 standard deviation. The contents of ashes, lipids and proteins in cashew kernels were 2.76, 47.2 , and $28.6 \%$ on average. Table 2 shows the results of the physical and chemical properties of each variety. Figure $3 \mathrm{~A}$ and Table 4 show the similarity relationships among accessions based on physicochemical traits. The supplementary material (Appendix) shows the results of ANOVAs for each characteristic that was tested to differentiate the cultivars.

\section{Genetic diversity}

Analyses with the RAPD and ISSR markers generated a total of 163 DNA bands, from which 159 were polymorphic (Table 3). Thus, the joint analysis provided $97.5 \%$ of polymorphism. The average of bands per primer was 8.13 polymorphic bands for RAPD and 5.1 for ISSR.

Using ISSR markers, TriCAT 3'RC was the most informative primer, amplifying seven bands (Fig. 4). Using RAPD markers, the most informative primer was OPA 02, producing 14 bands (Fig. 5).

The genetic dissimilarity coefficients among the twelve cashew cultivars ranged from 4.0 to 14.0. BRS 274 and BRS 275 were the cultivars with the highest similarity degree (4.0), while CCP 09 and BRS 189 were the most genetically distant (14.0, Table 5). Moreover, cutoff at $70 \%$ genetic similarity in the dendrogram arranged the cultivars into five subgroups (Fig. 3B).

Subgroup I clustered CCP 06, CCP 09, CCP 76, CCP 1001, EMBRAPA 50, and EMBRAPA 51. Subgroup II grou- ped BRS 226, BRS 274, and BRS 275. Subgroups III, IV, and $\checkmark$ were composed only of one clone: BRS 253, BRS 189, and BRS 265, respectively.

Correlation analysis between molecular markers and physicochemical characteristics

The correlation coefficient $(r=0.02)$ between the similarity matrices generated by the RAPD markers and physicochemical attributes was positive but not significant according to the Mantel test at $5 \%$ probability $(p=0.49)$. Also, the correlation coefficient ( $r=-0.04$ ) between the ISSR and physicochemical matrices was negative, and, although significant at $1 \%$ probability by the Mantel test, no correlation between these two matrices existed $(p=0.01)$.

\section{Discussion}

\section{Physicochemical traits}

The $\mathrm{pH}$ we observed (6.8) was similar to that reported by Liu et al. (2019) in cooked (6.14) and raw (6.20) cashew kernels. Moisture in cashew kernels is relatively high, and moisture content differed significantly among cultivars. However, the BRS 253 cultivar was irrelevant for the study because, at the beginning of the experiment, cashew kernels from this clone had high moisture due to the peel removal.

Peel removal under water vapor conditions may explain the higher initial moisture in kernels. Also, the other factors may affect moisture content evaluation, such as the method used. Moreover, the size of cashew kernels may affect water retention and removal, and, as the size is genetically inherited, moisture differed significantly among cultivars. Akinhanmi (2008) and Liu et al. (2019) reported $7.2 \%$ and 3.04 moisture, respectively.

Regarding ashes, the content was close to the value of $2.80 \%$ found by Akinhanmi (2008). Ashes are the inorganic substances present in food, that is, the mineral content. Minerals are essential for diet because they act as cofactors in many physiological processes. Cashew kernels are rich in minerals, mainly selenium, which acts as a powerful antioxidant (Souza et al., 2017).

The lipid content found (47.2\%) was similar to those found by Akinhanmi (2008) and Liu et al. (2019), 49.1 and $54.1 \%$, respectively. Cashew nuts are rich in oleic and 

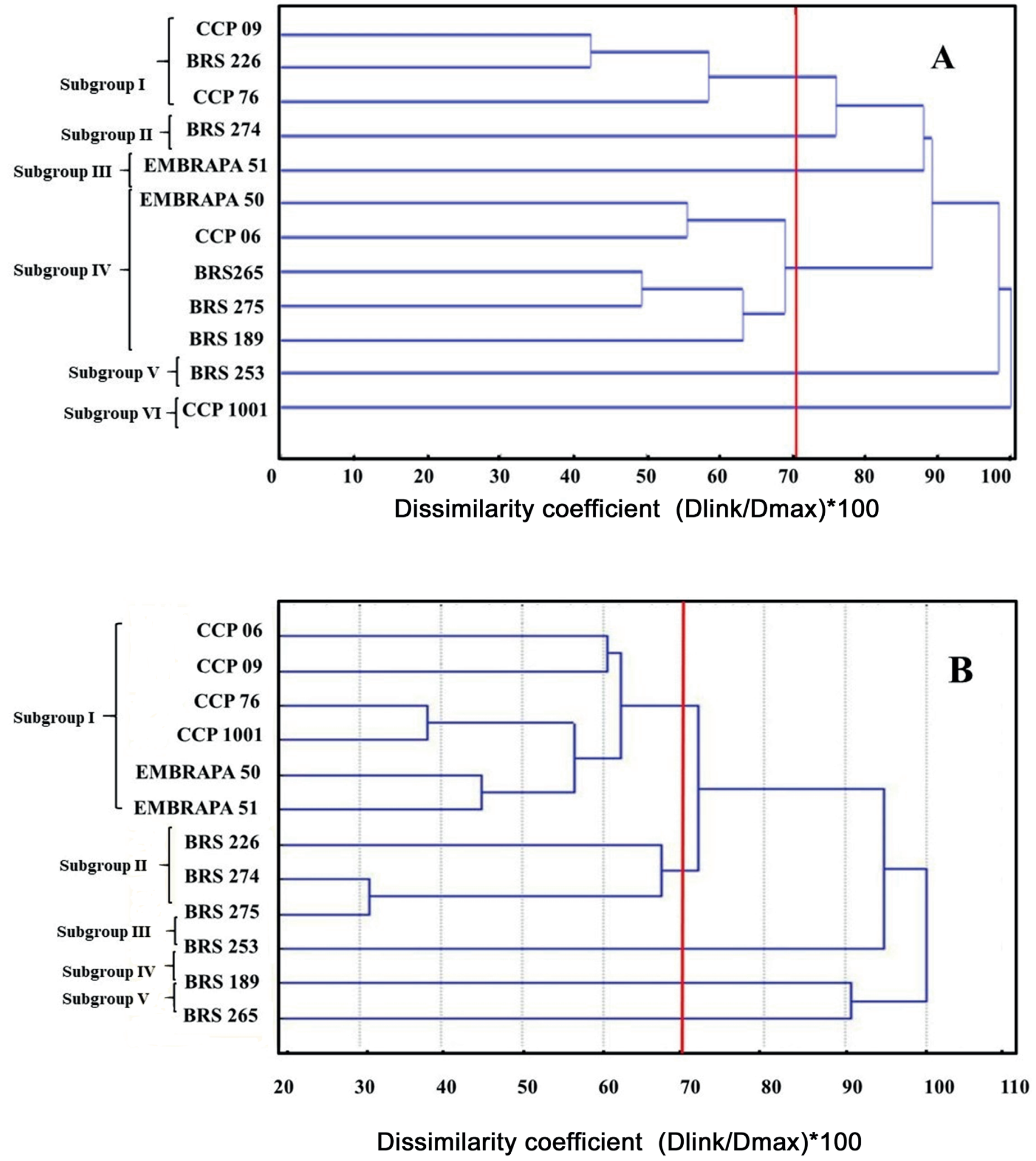

Figure 3: Dendrograms obtained from statistical analyses based on physicochemical (A) and molecular (B) data for the twelve cashew cultivars. A. the dendrogram was constructed using the UPGMA clustering method in the software Genes; $B$. the dendrogram was obtained in Statistica software. The red line indicates the cutoff point for arrangement of groups. 
Table 4: Euclidean distance matrix based on physicochemical characters in twelve cashew cultivars determined using Euclidean coefficient.

\begin{tabular}{|c|c|c|c|c|c|c|c|c|c|c|c|c|}
\hline & EMBRAPA 50 & EMBRAPA 51 & CCP 06 & СCP 09 & CCP 76 & ССР 1001 & BRS 189 & BRS 226 & BRS 253 & BRS 265 & BRS 274 & BRS 275 \\
\hline EMBRAPA 50 & 0.0 & 5.8 & 5.2 & 6.6 & 2.4 & 5.5 & 6.2 & 7.7 & 12.2 & 4.4 & 11.0 & 3.5 \\
\hline EMBRAPA 51 & & 0.0 & 4.4 & 3.5 & 4.5 & 3.2 & 11.5 & 2.1 & 9.4 & 4.5 & 5.6 & 5.8 \\
\hline ССР 06 & & & 0.0 & 7.6 & 5.7 & 5.5 & 9.4 & 5.5 & 8.2 & 1.01 & 7.2 & 2.5 \\
\hline ССР 09 & & & & 0.0 & 4.5 & 4.6 & 12.5 & 4.3 & 11.9 & 7.5 & 7.9 & 8.2 \\
\hline CCP 76 & & & & & 0.0 & 5.1 & 8.5 & 6.3 & 11.7 & 5.2 & 9.9 & 4.9 \\
\hline CCP 1001 & & & & & & 0.0 & 10.2 & 5.09 & 12.2 & 5.07 & 7.8 & 6.3 \\
\hline BRS 189 & & & & & & & 0.0 & 13.6 & 16.9 & 8.5 & 16.3 & 7.2 \\
\hline BRS 226 & & & & & & & & 0.0 & 8.2 & 5.9 & 3.7 & 7.3 \\
\hline BRS 253 & & & & & & & & & 0.0 & 9.1 & 7.10 & 9.7 \\
\hline BRS 265 & & & & & & & & & & 0.0 & 7.9 & 1.95 \\
\hline BRS 274 & & & & & & & & & & & 0.0 & 9.60 \\
\hline BRS 275 & & & & & & & & & & & & 0.0 \\
\hline
\end{tabular}

linoleic acids, fatty acids with therapeutic properties against cardiovascular diseases, besides controlling glycemia (Mohan et al., 2017).

On the other hand, the protein content $(28.6 \%)$ in the present study was higher than that obtained by Griffin and Dean (2017) in raw kernels (17.2\%), and lower than that found by Akinhanmi (2008), 36.3\%. Despite the differences in these contents, results support that cashew nuts are an abundant source of protein and amino acids. Rich in these compounds, such cashew kernels are useful for the food industry in providing value-added products (Liu et al., 2018).

\section{Genetic diversity}

According to Colombo et al. (1998), generating 50 to 200 polymorphic fragments in such analyses is sufficient for estimating genetic relationships within and between species. Similarly, using RAPD and ISSR markers to assess genetic diversity among 40 cashew cultivars from India, Thimmappaiah et al. (2016) found 163 bands, from which 129 were polymorphic, corresponding to $79.6 \%$ polymorphism. Castro et al. (2016), using the same markers to study the genetic diversity among 56 grapevine cultivars, observed that 145 fragments were amplified, from which 116 were polymorphic bands, an 80\% polymorphism. Thus, such results showed that both markers are effective in assessing genetic diversity.

Subgroup I junction in the dendrogram (Fig. 3B) is explained by the fact that CCP 09, CCP 76, and CCP 1001 were obtained from an individual phenotypic selection from a CCP
06 population. Also, because EMBRAPA 50 was generated from a cross between CCP 09 and CCP 76, the branch in the dendrogram joining the two cultivars is short, showing their genetic similarity. Moreover, EMBRAPA 51 originated within a cross-bred progeny of CCP 76, followed by clonal selection. Therefore, these latter cultivars are close to the group containing CCP 76 (Vidal Neto et al., 2013).

In Subgroup II, cultivars have different origins from the previous ones. BRS 226 was generated from an individual phenotypic selection of MAP-42, a mother plant of early dwarf cashew from Fazenda CAPISA, Piauí (Paiva and Barros, 2004). BRS 274, in turn, originated from an individual phenotypic selection of common cashews in a segregating population (Paiva, 2007a). On the other hand, BRS 275 was obtained by selection within a cross-pollination progeny, originating from cross between an early dwarf (CCP 1001) and a common cashew mother plant (CP 12) (Paiva, 2007b).

The clone BRS 253 in Subgroup III was generated by individual phenotypic selection from an early dwarf mother plant (P96D), which originated from a cross-bred progeny (Paiva, 2004). Thus, the origin explains why this clone was grouped apart.

Similarly, Subgroup IV grouped only the clone BRS 189. Although generated from the selection of progenies from crosses between CCP 1001 and CCP 76, BRS 189 was distant from its parents. Because the ISSR and RAPD markers can randomly access the DNA regions, common sequences between cultivars may not have been accessed in the analy- 


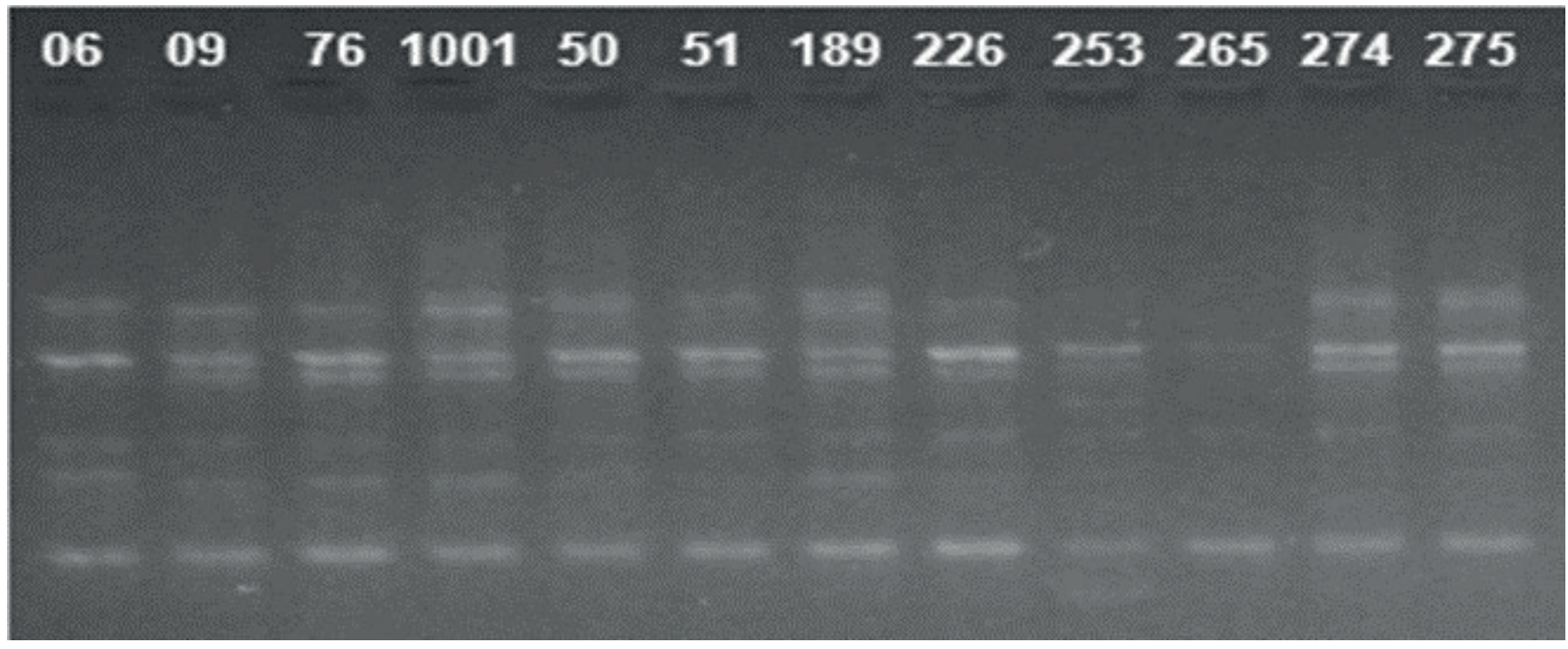

Figure 4: Amplification pattern of twelve cashew cultivars using the ISSR 04 primer. Numbers 06 to 275 correspond to the studied cultivars.

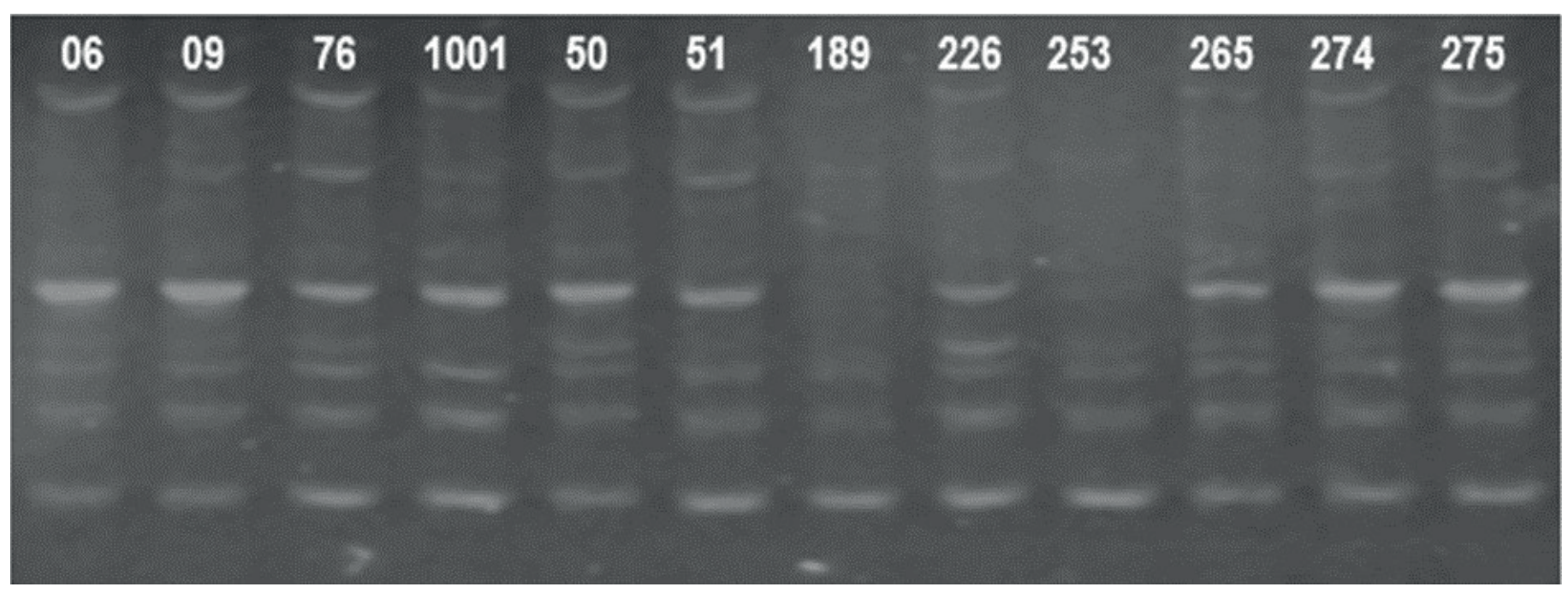

Figure 5: Amplification pattern of twelve cashew cultivars using the RAPD OPA 02 primer. Numbers 06 to 275 correspond to the studied cultivars.

sis, which explains the way the cultivars were grouped (Vidal Neto et al., 2013).

Finally, Subgroup V contained only a cultivar originated from an individual phenotypic selection within openpollinated progenies from the CCP 76 early dwarf cashew. However, both cultivars were not grouped because the markers did not access the common DNA sequences between them (Vidal Neto et al., 2013).

According to Pessoni (2007), the highest genetic diversity among cashew plants occurs within populations of the genus Anacardium, while lower variation results from differences among populations. Likewise, Carvalho et al. (2012) showed that $93.36 \%$ of the molecular variation among bushy cashew (Anacardium humile A. St.-Hill.) cultivars occurred within the population, while $6.64 \%$ was among those populations.

Analysis with the physicochemical markers showed that the genetic similarity between the cashew cultivars ranged from 2.199 to 16.900 . BRS 189 and BRS 253 were the most genetically distant genotypes, while EMBRAPA 51 
and BRS 226 were the closest ones (Table 4). In addition, cutoff at $70 \%$ genetic similarity arranged cultivars into six subgroups, as shown in the dendrogram (Fig. 3A). Subgroup I included CCP 09, BRS 226, and CCP 76. Subgroups II, III, V, and VII were composed just of BRS 274, EMBRAPA 51, BRS 253, and CCP 1001, respectively. Moreover, Subgroup IV was composed of EMBRAPA 50, CCP 06, BRS 265, BRS 275, and BRS 189. Furthermore, 0.63 cophenetic correlation coefficient (CCC) can be considered significant and of medium magnitude, indicating the consistency of the clustering.

Magalhães et al. (2018) found high genetic diversity among acerola (Malpighia emarginata DC.) cultivars, using physicochemical attributes. Similarly, using morphological characteristics, such as plant growth, flowering, fruit, and nut characters, Jena et al. (2016) found high variability among twelve cashew cultivars.

Regarding the origin, obtaining method, and respective parents of the twelve cultivars studied here (Paiva, 2004; 2007a, b; Vidal Neto et al., 2013), genetic diversity among the cultivars was low, considering the molecular analysis used. Also, the molecular data were not similar to the physicochemical ones.

Correlation analysis between molecular markers and physicochemical characteristics

Dasmohapatra et al. (2013), using ISSR markers and morphological traits to estimate genetic variability among 25 cashew varieties from India, obtained lower and non-significant correlation coefficient ( $r=0.005)$.

Environmental conditions influence the expression of physicochemical and other quantitative traits of agronomic interest. Also, such characteristics are subject to natural selection, which acts on genetic level, generating differences among plants of the same genus. Thus, plants with the same DNA sequences can express different DNA regions, which makes the correlation analysis difficult. However, despite the divergence between the generated clusters, some considerations must be made.

The cultivars BRS 189 and BRS 253 are distantly related, as shown in the dendrogram generated based on DNA markers (Fig. 3B). However, they had the highest protein and lipid contents, 34.2 and 54.6\%, respectively. Such plants can be used in future breeding programs to improve the contents of these compounds.

CCP 1001 showed the lowest moisture (3.36\%) among cultivars, pH close to neutrality (6.92), and low acidity $(0.73 \%)$ (Table 2$)$. Such attributes are important for the industry because they improve the conservation and taste of the cashew kernels. Also, moisture is difficult to determine because the process is influenced by peel removal and environmental conditions under which plants grow. In addition, because the cashew kernels from the CCP 1001 cultivar have low acidity, they can be eaten toasted, with good acceptance by consumers.

Table 5: Euclidean distance matrix based on RAPD and ISSR molecular markers in twelve cashew cultivars determined using Euclidean coefficient.

\begin{tabular}{|c|c|c|c|c|c|c|c|c|c|c|c|c|}
\hline & EMBRAPA 50 & EMBRAPA 51 & CCP 06 & CCP 09 & CCP 76 & CCP 1001 & BRS 189 & BRS 226 & BRS 253 & BRS 265 & BRS 274 & BRS 275 \\
\hline EMBRAPA 50 & 0 & 5.816 & 5.23 & 6.67 & 2.458 & 5.584 & 6.274 & 7.78 & 12.238 & 4.442 & 11.016 & 3.547 \\
\hline EMBRAPA 51 & & 0 & 4.484 & 3.557 & 4.593 & 3.219 & 11.556 & 2.199 & 9.488 & 4.551 & 5.635 & 5.823 \\
\hline CCP 06 & & & 0 & 7.671 & 5.767 & 5.524 & 9.477 & 5.543 & 8.203 & 1.015 & 7.272 & 2.544 \\
\hline CCP 09 & & & & 0 & 4.539 & 4.674 & 12.596 & 4.383 & 11.985 & 7.523 & 7.983 & 8.246 \\
\hline CCP 76 & & & & & 0 & 5.163 & 8.584 & 6.365 & 11.726 & 5.264 & 9.972 & 4.937 \\
\hline ССР 1001 & & & & & & 0 & 10.202 & 5.099 & 12.219 & 5.074 & 7.835 & 6.312 \\
\hline BRS 189 & & & & & & & 0 & 13.602 & 16.9 & 8.559 & 16.35 & 7.28 \\
\hline BRS 226 & & & & & & & & 0 & 8.275 & 5.953 & 3.795 & 7.317 \\
\hline BRS 253 & & & & & & & & & 0 & 9.157 & 7.106 & 9.748 \\
\hline BRS 265 & & & & & & & & & & 0 & 7.98 & 1.95 \\
\hline BRS 274 & & & & & & & & & & & 0 & 9.607 \\
\hline BRS 275 & & & & & & & & & & & & 0 \\
\hline
\end{tabular}


In conclusion, although the results obtained with the ISSR and RAPD markers were not similar, using more than one marker allows obtaining complementing results. It thus improves the strategies of conservation and the use of germplasm. There was no correlation between the molecular and physicochemical data and high variability was found among the cashew cultivars. The cashew kernels from the twelve cultivars studied here had low acidity and $\mathrm{pH}$, considerable moisture and ash contents, and high protein and lipid contents. BRS 189, BRS 253, and CCP 1001 showed the best values for proteins, lipids, acidity, and $\mathrm{pH}$. In addition, those cultivars have maximum distance genetic among them. Therefore, the results suggests that they are more suitable for breeding programmes.

\section{Author contributions}

LMS conceived the study and wrote the paper. ENL assisted as corresponding author and helped writing the paper. PNB and FCV supplied the material for this study (kernels and leaves) and contributed with revision of the paper. ISA supervised the experiments. All authors reviewed and approved the final manuscript.

\section{Funding}

This research was supported by the Universidade Federal Rural do Semi-Árido (UFERSA).

\section{Acknowledgements}

We would like to thank the research team of Juliana Rocha Vaez for providing the laboratory resources and conducible environment to carry out this work.

\section{Literature cited}

Akinhanmi, T. F., V. N. Atasie and P. O. Akintokun. 2008. Chemical composition and physicochemical properties of cashew nut (Anacardium occidentale) oil and cashew nut shell liquid. Journal of Agriculture, Food, and Environment 2(1): 1-10.

Brainer, M. S. C. P. and M. F. Vidal. 2018. Cajucultura nordestina em recuperação. Caderno Setorial Etene. 5 ed. Fortaleza, Brazil. 13 pp.

Carneiro, L. A., L. S. Silva, M. F. C. Gomes, M. F. Santos, S. E. S. Valente, R. L. F. Gomes and M. F. Costa. 2019. Morphological characterization and genetic divergence of a cashew popu- lation in Floriano, Piauí, Brazil. Genetics and Molecular Research 18(3): 1-8. DOI: https://doi.org/10.4238/gmr18348

Carvalho, R. S., J. F. N. Pinto, E. F. Reis, S. C. Santos and L. A. S. Dias. 2012. Variabilidade genética de cajuzinho-do-cerrado (Anacardium humile St. Hill.) por meio de marcadores rapd. Revista Brasileira de Fruticultura 34(1): 227-233. DOI: https://doi.org/10.1590/S0100-29452012000100030

Castro, I., O. Pinto-Carnide, J. M. Ortiz, V. Ferreira V and J. P. Martín. 2016. A comparative analysis of genetic diversity in Portuguese grape germplasm from ampelographic collections fit for quality wine production. Spanish Journal of Agricultural Research 14(4): 1-11. DOI: https://doi. org/10.5424/sjar/2016144-8852

Cavalcanti, J. J. V and L. M. Barros. 2009. Avanços, desafios e novas estratégias do melhoramento genético do cajueiro no Brasil. In: Vidal Neto, L. M., C. H. C. M. Bertini, F. A. S. Aragão and J. J. V. Cavalcanti (eds.). Simpósio nordestino de genética e Melhoramento de plantas. Embrapa. Fortaleza. Brazil. Pp. 83-101.

Cavalcanti, J. J. V., F. C. Vidal Neto and L. M. Barros. 2013. Avanços, desafios e novas estratégias do melhoramento genético do cajueiro no Brasil. In: Vidal Neto, F. C. and J. J. V. Cavalcanti (eds.). Melhoramento Genético de Plantas no Nordeste. Embrapa. Brasília. Brazil. Pp. 151-174.

Colombo, C., G. Second, T. Losada Valle and A. Charrier. 1998. Genetic diversity characterization of cassava cultivars (Manihot esculenta Crantz). I) RAPD markers. Genetics and Molecular Biology 21(1): 105-113. DOI: https://doi.org/10.1590/ S1415-47571998000100018

Cruz, C. D. 2013. Genes-a software package for analysis in experimental statistics and quantitative genetics. Acta Scientiarum Agronomy 35(3): 271-276. DOI: https://doi.org/10.4025/ actasciagron.v35i3.21251

Dasmohapatra, R., S. Rath and G. R. Rout. 2013. Analysis of genetic relationships in cashew (Anacardium occidentale L.) varieties using morphological characters and ISSR markers. Journal of Plant Breeding and Crop Science 41(3): 321-329.

Faleiro, F. G. 2007. Marcadores genético-moleculares aplicados a programas de conservação e uso de recursos genéticos. Embrapa Cerrados. Brasília, Brazil. 99 pp.

Ferreira, M. E and D. Grattapaglia. 1995. Introdução ao uso de marcadores RAPD e RFLP em análise genética. Embrapa Recursos Genéticos e Biotecnologia. Brasília, Brazil. 220 pp. 
Figueirêdo, M. C. B, J. Potting, L. A. L. Serrano, M. A. Bezerra, V. da. Silva Barros, R. S. Gondim and T. Nemecek. 2016. Environmental assessment of tropical perennial crops: the case of the Brazilian cashew. Journal of Cleaner Production 112: 131140. DOI: https://doi.org/10.1016/j.jclepro.2015.05.134

Freitas, A. S. D., B. D. S. Dantas, Í. M. D. S. Araújo and D. D. S. Garruti. 2020. Suitability of peduncles of new cashew tree clones for commercial purposes. Revista Ciência Agronômica 51(3): 1-8. DOI: https://doi.org/10.5935/1806-6690.20200050

Gadani, B. C., K. M. L. Miléski, L. S. Peixoto and J. D. S. Agostini. 2017. Physical and chemical characteristics of cashew nut flour stored and packaged with different packages. Food Science and Technology 37(4): 657-662. DOI: https://doi. org/10.1590/1678-457x.27516

Griffin, L. E. and L. L. Dean. 2017. Nutrient composition of raw, dry-roasted, and skin-on cashew Nuts. Journal of Food Research 6: 1-16. DOI: https://doi.org/10.5539/jfr.v6n6p13

Hammer, Ø., D. A. T. Harper and P. D. Ryan. 2001. PAST: Paleontological statistics software package for education and data analysis. Palaeontologia electronica 4(1): 1-9.

IAL. 2008. Normas Analíticas do Instituto Adolfo Lutz. Métodos físico-químicos para análises de alimentos. 4 ed. Rio de Janeiro, Brazil. 1020 pp.

IBGE. 2020. Levantamento Sistemático da Produção Agrícola. Instituto Brasileiro de Geografia e Estatística. Brazil. https:// sidra.ibge.gov.br/home/lspa/brasil/ (consulted December, 2020).

Jena, R. C., K. Samal, A. Pal, B. K. Das and P. K. Chand. 2016. Genetic diversity among some promising Indian local selections and hybrids of cashew nut based on morphometric and molecular markers. International Journal of Fruit Science 16(1): 6993. DOI: https://doi.org/10.1080/15538362.2015.1046321

Kirk, P. L. 1950. Kjeldahl method for total nitrogen. Analytical Chemistry 22(2): 354-358. DOI: https://doi.org/10.1021/ ac60038a038

Liu, Y., X. Li, Y. Liang, J. Liang, D. Deng and J. Li. 2019. Comparative study on the physicochemical characteristics and fatty acid composition of cashew nuts and other three tropical fruits. IOP Conference Series: Earth and Environmental Science 310(5): 1-8. DOI: https://doi.org/10.1088/1755$1315 / 310 / 5 / 052011$

Liu, C. M, Q. Peng, J.-Z. Zhong, W. Liu, Y.-J. Zhong and F. Wang. 2018. Molecular and functional properties of protein frac- tions and isolate from cashew nut (Anacardium occidentale L.). Molecules 23(2): 393-408. DOI: https://doi.org/10.3390/ molecules23020393

Magalhães, D. S, J. C. M. Rufini, A. S. Alburquerque, R. E. Viol, M. C. P. Fagundes and T. P. Menezes. 2018. Genetic diversity among accessions of acerola based on the quality of fruits. Comunicata Scientiae 9: 133-141. DOI: https://doi. org/10.14295/CS.v9i2.2961

Mohan, V., R. Gayathri, L. M. Jaacks, N. Lakshmipriya, R. M. Anjana, D. Spiegelman, R. G. Jeevan, K. K. Balasubramaniam, S. Shobana, M. Jayanthan, V. Gopinath, S. Divya, V. Kavitha, P. Vijayalakshmi, M. R. Bai, R. Unnikrishnan, V. Sudha, K. Krishnaswamy, J. Salas-Salvadó and W. C. Willett. 2017. Cashew nut consumption increases HDL cholesterol and reduces systolic blood pressure in Asian Indians with type 2 diabetes: A 12-week randomized controlled trial. Journal of Nutrition 148(1): 63-69. DOI: https://doi.org/10.1093/jn/nxx001

Nadeem, M. A., M. A. Nawaz, M. Q. Shahid, Y. Doğan, G. Comertpay, M. Yıldız, R. Hatipoğlu, F. Ahmad, A. Alsaleh, N. Labhane, H. Özkan and F. S. Baloch. 2018. DNA molecular markers in plant breeding: current status and recent advancements in genomic selection and genome editing. Biotechnology and Biotechnological Equipment. 32(2): 261-285. DOI: https:// doi.org/10.1080/13102818.2017.1400401

Oliveira, N. N., C. Gonçalves Mothé, M. Gonçalves Mothé and L. Guimarães de Oliveira. 2020. Cashew nut and cashew apple: a scientific and technological monitoring worldwide review. Journal of Food Science and Technology 57(1): 1221. DOI: https://doi.org/10.1007/s13197-019-04051-7

Paiva, R. J. 2004. BRS 253 ou BRS Bahia 12 clone. Embrapa Agroindústria Tropical. 1 ed. Fortaleza, Brazil. 6 pp.

Paiva, R. J. 2007a. BRS 274 (BRS cultivar Jacaju) clone de cajueiro comum. Embrapa Agroindústria Tropical. 1 ed. Fortaleza, Brazil. 6 pp.

Paiva, R. J. 2007b. BRS 275 híbrido de cajueiro anão versus comum (BRS Dão cultivar). 1 ed. Embrapa Agroindústria Tropical. 1 ed. Fortaleza, Brazil. 6 pp.

Paiva, J. R. and L. M. Barros. 2004. Cultivares de cajueiro: obtenção, características e perspectivas. Embrapa Agroindústria Tropical. 1 ed. Fortaleza, Brazil. 26 pp.

Pessoni, L. A. 2007. Strategies for the analysis of genetic diversity in cashew germplasm (Anacardium spp. L.). Doctoral thesis. Universidade Federal de Viçosa. Viçosa, Brazil. 174 pp. 
Salehi, B., M. Gültekin-Özgüven, C. Kirkin, B. Özçelik, M. F. B. Morais-Braga, J. N. P. Carneiro., C. F. Bezerra, T. G. da Silva, H. D. M. Coutinho, B. Amina, L. Armstrong, Z. Selamoglu, M. Sevindik, Z. Yousaf, J. Sharifi-Rad, A. M. Muddathir, H. P. Devkota, M. Martorell, A. K. Jugran., Martins N. and C. W. Cho. 2019. Anacardium plants: chemical, nutritional composition and biotechnological applications. Biomolecules 9(9): 1-34. DOI: https://doi.org/10.3390/biom9090465

Santana, I. B. B., E. J. Oliveira, W. S. Soares Filho, R. Ritzinger, E. P. Amorim, M. A. P. de Carvalho Costa and R. F. C. Moreira. 2011. Variabilidade genética entre acessos de Umbu-Cajazeira mediante análise de marcadores ISSR. Revista Brasileira de Fruticultura 33(3): 868-876. DOI: https://doi. org/10.1590/S0100-29452011005000090

Serrano, L. A. L. and P. F. A. P. Pessoa. 2016. Aspectos econômicos da cultura do cajueiro. In: Serrano, L. A. L. (ed.). Sistema de Produção do Caju. Embrapa. Brasília. Brazil. Pp. 1-6.

Sethi, K., S. K. Tripathy, P. C. Lenka and P. Mohanty. 2016. Molecular assessment of genetic diversity and identification of elite cashew hybrids. International Horticulture Journal 6: 1-10. DOI: https://doi.org/10.5376/ijh.2016.06.0002

Souza, R. G. M., R. M. Schincaglia, G. D. Pimentel and J. F. Mota. 2017. Nuts and human health outcomes: a systematic review. Nutrients 9(12): 1-23. DOI: https://doi.org/10.3390/ nu9121311

Thimmappaiah, S. D, G. S. Mohana, J. D. Adiga and P. G. Bhat. 2016. Fingerprinting of released varieties of cashew based on DNA markers. Vegetos: An International Journal of Plant Research 29(4): 89-95. DOI: https://doi.org/10.5958/22294473.2016.00105.1

Vidal Neto, F. C., L. M. Barros, J. J. V. Cavalcanti and D. S. Melo. 2013. Melhoramento genético e cultivares de cajueiro. In: Vidal Neto, F. C. and J. J. V. Cavalcanti (eds.). Melhoramento Genético de Plantas no Nordeste. Embrapa. Brasília. Brazil. Pp. 481-508.

Weiß, C. H. 2007. Statistica, Version 8. Advances in statistical analysis 91: 339-341. DOI: https://doi.org/10.1007/s10182007-0038-x 
Appendix: Comparisons by One-Way ANOVA among kernel physicochemical characters from twelve cashew cultivars.

\begin{tabular}{|c|c|c|c|c|c|c|c|c|c|c|c|c|}
\hline & EMBRAPA 50 & EMBRAPA 51 & ССР 06 & ССР 09 & ССР 76 & CCP 1001 & BRS 189 & BRS 226 & BRS 253 & BRS 265 & BRS 274 & BRS 275 \\
\hline \multicolumn{13}{|l|}{$\mathrm{pH}$} \\
\hline EMBRAPA 50 & & 0,001611 & 0.99 & 0.03957 & 0.1357 & 0.9845 & 0.9669 & 0.05273 & 0.08012 & 0.7725 & 0.1739 & 0.008786 \\
\hline EMBRAPA 51 & 7.222 & & 0.02192 & 0.954 & 0.6956 & 0.02545 & 0.0342 & 0.9187 & 0.8403 & 0.1048 & 0.6134 & 0.9998 \\
\hline CCP 06 & 1.595 & 5.628 & & 0.339 & 0.6956 & 1 & 1 & 0.4108 & 0.5302 & 0.9998 & 0.7725 & 0.1048 \\
\hline ССР 09 & 5.253 & 1.97 & 3.658 & & 1 & 0.374 & 0.4493 & 1 & 1 & 0.7725 & 0.9998 & 0.9999 \\
\hline CCP 76 & 4.408 & 2.814 & 2.814 & 0.8442 & & 0.735 & 0.8078 & 1 & 1 & 0.9769 & 1 & 0.9769 \\
\hline CCP 1001 & 1.688 & 5.534 & 0.0938 & 3.564 & 2.72 & & 1 & 0.4493 & 0.5717 & 0.9999 & 0.8078 & 0.1194 \\
\hline BRS 189 & 1.876 & 5.346 & 0.2814 & 3.377 & 2.532 & 0.1876 & & 0.5302 & 0.6549 & 1 & 0.8698 & 0.1538 \\
\hline BRS 226 & 5.065 & 2.157 & 3.14 & 0.1876 & 0.6566 & 3.377 & 3.189 & & 1 & 0.8403 & 1 & 0.9995 \\
\hline BRS 253 & 4.784 & 2.439 & 3.189 & 0.0469 & 0.3752 & 3.095 & 2.908 & 0.2814 & & 0.9187 & 1 & 0.9964 \\
\hline BRS 265 & 2.626 & 4.596 & 1.032 & 2.626 & 1.782 & 0.938 & 0.7504 & 2.439 & 2.157 & & 0.99 & 0.374 \\
\hline BRS 275 & 6.191 & 1.032 & 4.596 & 0.938 & 1.782 & 4.502 & 4.315 & 1.126 & 1.407 & 3.564 & 1.97 & \\
\hline \multicolumn{13}{|l|}{ Acidity } \\
\hline EMBRAPA 50 & & 0.08086 & 0.1212 & 0.08086 & 0.6625 & 0.08086 & 0.08086 & 0.08086 & 0.3687 & 0.08086 & 0.1212 & 0.08086 \\
\hline EMBRAPA 51 & 1 & & 0.3827 & 0.08086 & 1 & 0.08086 & 0.08086 & 0.08086 & 0.08086 & 0.08086 & 0.08086 & 0.08086 \\
\hline ССР 06 & 1 & 1 & & 0.08086 & 0.6625 & 0.08086 & 0.08086 & 0.08086 & 0.2683 & 0.08086 & 0.08086 & 0.08086 \\
\hline ССР 09 & 1 & 1 & 1 & & 0.08086 & 0.3687 & 0.8248 & 0.08086 & 0.08086 & 0.08086 & 0.08086 & 0.3687 \\
\hline CCP 76 & 1 & 1 & 1 & 1 & & 0.08086 & 0.08086 & 0.1904 & 0.6625 & 0.1904 & 0.1904 & 0.08086 \\
\hline CCP 1001 & 1 & 1 & 1 & 1 & 1 & & 0.8248 & 0.08086 & 0.08086 & 0.08086 & 0.08086 & 1 \\
\hline BRS 189 & 1 & 1 & 1 & 1 & 1 & 1 & & 0.3827 & 0.08086 & 0.2683 & 0.3827 & 0.8248 \\
\hline BRS 226 & 1 & 1 & 1 & 1 & 1 & 1 & 1 & & 0.08086 & 0.5066 & 1 & 0.08086 \\
\hline BRS 253 & 1 & 1 & 1 & 1 & 1 & 1 & 1 & 1 & & 0.08086 & 0.08086 & 0.08086 \\
\hline BRS 274 & 1 & 1 & 1 & 1 & 1 & 1 & 1 & 1 & 1 & 1 & & 0.08086 \\
\hline BRS 275 & 1 & 1 & 1 & 1 & 1 & 1 & 1 & 1 & 1 & 1 & 1 & \\
\hline \multicolumn{13}{|l|}{ Moisture } \\
\hline EMBRAPA 50 & & 0.0001429 & 0.9683 & 0.0001429 & 0.3146 & 0.0001429 & 0.0001429 & 0.0005612 & 0.0001429 & 0.007412 & 0.000143 & 0.00523 \\
\hline EMBRAPA 51 & 14.73 & & 0.0001429 & 1 & 0.0001429 & 0.0001429 & 1 & 0.003081 & 0.0001429 & 0.0002997 & 0.6502 & 0.0001429 \\
\hline ССР 06 & 1.864 & 12.87 & & 0.0001429 & 0.02325 & 0.0001429 & 0.0001429 & 0.0111 & 0.0001429 & 0.1317 & 0.0001508 & 0.0003219 \\
\hline ССР 09 & 14.14 & 0.5978 & 12.27 & & 0.0001429 & 0.0001429 & 1 & 0.008318 & 0.0001429 & 0.0006229 & 0.8759 & 0.0001429 \\
\hline CCP 76 & 3.727 & 18.46 & 5.591 & 18.86 & & 0.0001429 & 0.0001429 & 0.0001431 & 0.0001429 & 0.0001497 & 0.0001429 & 0.7109 \\
\hline CCP 1001 & 39.2 & 24.47 & 37.34 & 25.07 & 42.93 & & 0.0001429 & 0.0001429 & 0.0001429 & 0.0001429 & 0.0001429 & 0.0001429 \\
\hline BRS 189 & 14.35 & 0.3868 & 12.48 & 0.211 & 18.07 & 24.86 & & 0.005871 & 0.0001429 & 0.0004658 & 0.8081 & 0.0001429 \\
\hline BRS 226 & 7.912 & 6.822 & 6.048 & 6.224 & 11.64 & 31.29 & 6.435 & & 0.0001429 & 0.9888 & 0.2575 & 0.0001429 \\
\hline BRS 253 & 53.73 & 68.46 & 55.59 & 67.86 & 50 & 92.93 & 68.07 & 61.64 & & 0.0001429 & 0.0001429 & 0.0001429 \\
\hline BRS 265 & 6.294 & 8.439 & 4.43 & 7.841 & 10.02 & 32.91 & 8.052 & 1.617 & 60.02 & & 0.026 & 0.0001429 \\
\hline BRS 274 & 11.81 & 2.918 & 9.951 & 2.321 & 15.54 & 27.39 & 2.532 & 3.903 & 65.54 & 5.521 & & 0.0001429 \\
\hline BRS 275 & 6.505 & 21.24 & 8.369 & 20.64 & 2.778 & 45.71 & 20.85 & 14.42 & 47.22 & 12.8 & 18.31 & \\
\hline \multicolumn{13}{|l|}{ Ashes } \\
\hline EMBRAPA 50 & & 1 & 0.08086 & 0.3827 & 0.08086 & 0.08086 & 0.1904 & 0.8248 & 0.08086 & 0.08086 & 0.08086 & 0.3827 \\
\hline EMBRAPA 51 & 1 & & 0.08086 & 0.3827 & 0.08086 & 0.08086 & 0.08086 & 0.6625 & 0.08086 & 0.08086 & 0.08086 & 0.1904 \\
\hline ССР 06 & 1 & 1 & & 0.08086 & 0.6625 & 0.08086 & 0.08086 & 0.08086 & 0.08086 & 0.08086 & 0.08086 & 0.08086 \\
\hline ССР 09 & 1 & 1 & 1 & & 0.08086 & 0.08086 & 0.08086 & 0.6625 & 0.1904 & 0.08086 & 0.08086 & 0.08086 \\
\hline CCP 76 & 1 & 1 & 1 & 1 & & 0.08086 & 0.08086 & 0.08086 & 0.08086 & 0.08086 & 0.08086 & 0.08086 \\
\hline CCP 1001 & 1 & 1 & 1 & 1 & 1 & & 0.08086 & 0.08086 & 0.08086 & 0.08086 & 1 & 0.08086 \\
\hline
\end{tabular}


Appendix: Continuation.

\begin{tabular}{|c|c|c|c|c|c|c|c|c|c|c|c|c|}
\hline & EMBRAPA 50 & EMBRAPA 51 & CCP 06 & ССР 09 & CCP 76 & ССР 1001 & BRS 189 & BRS 226 & BRS 253 & BRS 265 & BRS 274 & BRS 275 \\
\hline BRS 253 & 1 & 1 & 1 & 1 & 1 & 1 & 1 & 1 & & 0.08086 & 0.3827 & 0.08086 \\
\hline BRS 265 & 1 & 1 & 1 & 1 & 1 & 1 & 1 & 1 & 1 & & 0.08086 & 0.1904 \\
\hline BRS 274 & 1 & 1 & 1 & 1 & 1 & 1 & 1 & 1 & 1 & 1 & & 0.08086 \\
\hline BRS 275 & 1 & 1 & 1 & 1 & 1 & 1 & 1 & 1 & 1 & 1 & 1 & \\
\hline \multicolumn{13}{|l|}{ Lipids } \\
\hline EMBRAPA 50 & & 0.07652 & 0.08086 & 0.1904 & 0.1904 & 0.08086 & 0.08086 & 0.08086 & 0.08086 & 0.08086 & 0.08086 & 0.08086 \\
\hline EMBRAPA 51 & 1 & & 0.184 & 0.3758 & 0.07652 & 0.07652 & 0.07652 & 0.07652 & 0.07652 & 0.6579 & 0.07652 & 0.07652 \\
\hline CCP 06 & 1 & 1 & & 0.080086 & 0.08086 & 0.08086 & 0.08086 & 0.08086 & 0.08086 & 0.6625 & 0.08086 & 0.08086 \\
\hline ССР 09 & 1 & 1 & 1 & & 0.6625 & 1 & 0.08086 & 0.08086 & 0.08086 & 0.8248 & 0.08086 & 0.6625 \\
\hline CCP 76 & 1 & 1 & 1 & 1 & & 0.3827 & 0.08086 & 0.08086 & 0.08086 & 0.3827 & 0.08086 & 1 \\
\hline CCP 1001 & 1 & 1 & 1 & 1 & 1 & & 0.08086 & 0.08086 & 0.08086 & 1 & 0.08086 & 0.6625 \\
\hline BRS 189 & 1 & 1 & 1 & 1 & 1 & 1 & & 0.08086 & 0.08086 & 0.08086 & 0.08086 & 0.08086 \\
\hline BRS 226 & 1 & 1 & 1 & 1 & 1 & 1 & 1 & & 0.08086 & 0.08086 & 0.08086 & 0.08086 \\
\hline BRS 253 & 1 & 1 & 1 & 1 & 1 & 1 & 1 & 1 & & 0.08086 & 1 & 0.08086 \\
\hline BRS 265 & 1 & 1 & 1 & 1 & 1 & 1 & 1 & 1 & 1 & & 0.08086 & 0.6625 \\
\hline BRS 274 & 1 & 1 & 1 & 1 & 1 & 1 & 1 & 1 & 1 & 1 & & 0.08086 \\
\hline BRS 275 & 1 & 1 & 1 & 1 & 1 & 1 & 1 & 1 & 1 & 1 & 1 & \\
\hline \multicolumn{13}{|l|}{ Proteins } \\
\hline EMBRAPA 50 & & 0.9245 & 0.9997 & 0.1854 & 0.9867 & 0.8382 & 0.4086 & 0.7589 & 1 & 0.9994 & 0.9075 & 0.9906 \\
\hline EMBRAPA 51 & 2.131 & & 0.521 & 0.9424 & 1 & 1 & 0.02266 & 1 & 0.8897 & 0.4898 & 1 & 0.3194 \\
\hline СCP 06 & 1.079 & 3.21 & & 0.03974 & 0.7298 & 0.3896 & 0.8538 & 0.3103 & 0.9999 & 1 & 0.4887 & 1 \\
\hline ССР 09 & 4.171 & 2.04 & 5.25 & & 0.8133 & 0.9817 & 0.0008275 & 0.9935 & 0.1538 & 0.03554 & 0.9546 & 0.01791 \\
\hline CCP 76 & 1.654 & 0.477 & 2.733 & 2.517 & & 1 & 0.04777 & 0.9998 & 0.9754 & 0.6995 & 1 & 0.5095 \\
\hline CCP 1001 & 2.445 & 0.314 & 3.524 & 1.726 & 0.7911 & & 0.01365 & 1 & 0.7869 & 0.362 & 1 & 0.2219 \\
\hline BRS 189 & 3.476 & 5.607 & 2.397 & 7.647 & 5.13 & 5.921 & & 0.009595 & 0.4682 & 0.8755 & 0.02011 & 0.9647 \\
\hline BRS 226 & 2.661 & 0.5298 & 3.74 & 1.51 & 1.007 & 0.2157 & 6.137 & & 0.6995 & 0.2862 & 1 & 0.169 \\
\hline BRS 253 & 0.1438 & 2.275 & 0.9349 & 4.315 & 1.798 & 2.589 & 3.332 & 2.805 & & 0.9998 & 0.8685 & 0.9957 \\
\hline BRS 265 & 1.151 & 3.282 & 0.07191 & 5.322 & 2.805 & 3.596 & 2.325 & 3.811 & 1.007 & & 0.4579 & 1 \\
\hline BRS 274 & 2.205 & 0.07431 & 3.284 & 1.966 & 0.5513 & 0.2397 & 5.681 & 0.4555 & 2.349 & 3.356 & & 0.2941 \\
\hline BRS 275 & 1.582 & 3.713 & 0.5034 & 5.753 & 3.236 & 4.027 & 1.894 & 4.243 & 1.438 & 0.4315 & 3.788 & \\
\hline
\end{tabular}

